\title{
Strategic thinking in a pandemic: \\ A Blueprint for Government-led National Hygiene Communication Campaigns to combat COVID-19
}

Val Curtis1, Robert Dreibelbis1, Myriam Sidibe2, Jason Cardosi3, Jennifer Sara4, Chris Bonell1, Kaposo Mwambuli3, Soma Ghosh Moulik, Sian White1, Robert Aunger1.

1. London School of Hygiene and Tropical Medicine

2. Harvard University

3. Project CLEAR

4. The World Bank

This is a working paper that had not yet been peer reviewed

\begin{abstract}
Whilst large-scale changes in population behaviour are required to reduce the transmission of the SARS-COV-2 pandemic virus, the emergency context is not conducive to the sort of careful communications planning that would normally be required to meet such a task. Rapid strategic communications planning in a pandemic by governments is, however, possible and necessary. Steps include setting up a dedicated communications task force, mobilising partners and resources, developing a creative brief and theory of change and overseeing the creation, testing, roll out and revision of content. In this short guide we argue that a minimum of strategic planning can be undertaken rapidly, and that good use can be made of simple principles of behaviour change, even during pandemics. Our aim here is to provide a blueprint that governments and their partners, especially in lowincome settings, can follow to design, coordinate and resource national communications efforts to combat the COVID-19 pandemic.
\end{abstract}




\title{
Strategic thinking in a pandemic: A Blueprint for Government-led National Hygiene Communication Campaigns to combat COVID-19
}

\author{
Background \\ Governments across the world are responding to the COVID-19 pandemic with \\ measures that include implementing communications campaigns to promote \\ behaviours that can reduce transmission of the virus in their communities. These \\ behaviours include hand hygiene, physical distancing, surface disinfection and mask \\ wearing as well as specific measures for particular populations such as isolation of \\ the vulnerable. However, very rapid population-scale behaviour change, such as that \\ which is required to contain a pandemic, can be difficult to achieve, and sustain, \\ even in the best of times. Some behaviours may be new, requiring new routines, \\ new infrastructure, new products and new norms. Some behaviours can be \\ infeasible in the socio-economic context in which they are being expected. On the \\ other hand outbreaks can also catalyse changes in behaviour. 12 In the pressured \\ environment of a public health emergency, it is especially hard to carry out strategic \\ communications planning that can lead to effective programming since immediate \\ and urgent responses tend to be prioritised. 3
}

Of course, strategic communications programmes have only a part to play in a national response; many other measures will be needed to help reduce the risk of viral transmission, including changes to social support systems and to the physical environment. It is hard to practice hand hygiene for example without WASH (Water Sanitation and Hygiene) infrastructure and supplies, for example. Efforts to change behaviour may also have negative effects. Physical distancing measures can cause losses to livelihoods (https://foreignpolicy.com/2020/04/10/poor-countries-socialdistancing-coronavirus/) reduce access to healthcare for other conditions, or reduce people's ability to pay for services such as water and sanitation. Nevertheless, coherent communications about expected behaviour remain a prime responsibility of government institutions.

Whilst country or regional governments need to design communications campaigns that are appropriate to their particular contexts, there are some key principles that apply across settings. Here we set out 10 essential steps in the development of a national communications strategy and outline 6 principles drawn from behavioural science on effective communications for behaviour change to aid rapid, but strategic, thinking on designing pandemic communication campaigns. In providing this guidance, we draw on the experience of multiple national campaigns on hygiene in domestic settings in low income countries. 4567 Our aim here is to provide a short blueprint for countries and their development partners wishing to enhance their national COVID-19 communications activities.

\section{Ten steps in developing a national communications strategy for COVID-19 prevention}

1. Set up a task force and appoint a national focal person

2. Mobilise resources and involve the private sector

3. Define exactly which behaviours need to change and by whom 
4. Review what is already being done internationally and locally

5. Review what is known about the drivers of these behaviours and rapidly fill in gaps in knowledge

6. Produce a creative brief and theory of change

7. Develop a unifying national brand

8. Develop executions employing the most relevant channels for the target audiences

9. Rapidly pre-test and continually revise

10. Deliver, monitor, evaluate, and share lessons

\section{Six behavioural principles to guide the development of communication strategies}

1. Do it for others - hygiene protects others - invoke motives of nurture, affiliation and justice

2. Act together - focus on how everyone is doing it (not on the cheaters)

3. Facilitate trust - trust means transparency

4. Make it possible - performance

5. Get attention - surprise

6. Emphasize reward - a better future will result

Below we outline these steps and principles in more detail, beginning with the steps in developing a national communications strategy to reduce the risk of COVID-19 transmission.

\section{Developing a national behaviour change communications strategy}

1. Set up a communications task force and appoint a national focal person Whilst many governments have assigned political responsibility and created highlevel committees on the COVID-19 response, these tend to concentrate on urgent matters such as provision of care, supplies and testing. Promotion of daily domestic practices such as handwashing is often seen as lower in priority but still requires an urgent and specific focus. 7 Whilst existing public health promotion teams will have been mobilised, it can be useful to reinforce them through the designation of a National Focal Person with sole responsibility for pandemic behaviour change planning. Their role is to champion and coordinate national communications activities. The chosen national focal person will need technical experience in communications, marketing, cross-sectoral coordination and public health, and combine this with personal qualities of energy, persistence, open-mindedness, a problem-solving focus, communications and networking skills and motivational leadership. $6 \mathrm{Her} / \mathrm{his}$ role is to assure a joined-up approach to national communications across all channels and by all partners (as far as is possible in an emergency). S/he may be seated in the Ministry of Health but must coordinate across the full range of ministries and cabinet offices that will contribute to the response. Aside from technical leadership, the focal person will need to be able to lead the national effort, bringing together all key stakeholders around a step-by step strategy and a unifying brand. 
The national focal person will need the support of a small, agile, action-oriented, task force which can execute the communications strategy. This task force should draw on locally specific skills and resources, but could include the MoH's health promotion unit, private sector representatives, media, behavioural scientists, and/or creative and communications specialists. The task force should not replace, but complement, existing coordinating structures, for example, under the cabinet or the UN, and seek to amplify their ability to mobilise expertise, reach and resources under national leadership. An example is the Swaach Bharat Mission in India which successfully transformed sanitation provision across the country by using a task-force, resultsoriented, approach, co-opting young, energetic staff to mobilise activity within the bureaucracy of a line Ministry. 6

\section{Mobilise resources, including from the private sector}

Financial and human resources are being mobilised globally towards COVID-19 prevention. National governments have the mandate to ensure that these are harnessed towards the Government's agreed goals, that efforts complement each other and that they use evidence-based approaches. Governments can source funds from national budgets, from loans and donations, by switching existing programmes towards the pandemic response and/or by approaching Industry. Some portions of such funding are usually dedicated for public communication. Such allocations, if not planned strategically, will be reallocated. Countries with well-thought-out communications strategies often find themselves at the head of the queue when applying to banks, multilateral and unilateral donors and granting foundations. Funders are finding, for example that they are getting disproportionate numbers of applications from countries such as Bangladesh and Pakistan that have welldeveloped relationships with donors and a lot of experience in communications planning. Such countries may leave other countries behind in competition for scarce resources. The better a country, task force or focal point can organise and articulate what is being asked for, the more, and faster, resources will be forthcoming.

Governments are generally well used to seeking the support of external agencies such as the development banks, the bilateral donors and the international NGOs. However, in the current context, mobilising finance may be less of a problem than mobilising human capital. A sophisticated communications campaign needs the support of experts in behaviour, in content development, in media buying, planning and influencing, and in monitoring outputs so as to gauge impact. Industry has special skills in this respect. Whilst governments' may expect that companies will want to make donations of products such as soap, industry can make a much more valuable contributions to the prevention effort - their particular ability in marketing to consumers (behaviour change by another name). Companies are competing to join the COVID-19 response, and are keen to gain government approval for their efforts, both because it increases their reach and enhances their legitimacy in the social field. 8

Industry has skills and capacities that are invaluable for national communications campaigns. They understand the need for unification around a single 'brand' (in this case the national COVID-19 brand - see below) and how to create such a thing. They have access to professional creative companies and individuals, who can craft messages and bring them to life, ensuring that the content of messaging is not just informational, but surprising, motivating and feasible.9 10 In other words, ensuring 
that it is not just the right message that is being diffused but that the message is right. ${ }_{11}$ For example, most current COVID-19 communications efforts are still entirely focused on the provision of information, yet it is doubtful that information alone is sufficient to change behaviour. 1

Industry also understands media planning, through being able to model how far resources invested in which channel will reach a specific set of the target population and how to monitor the reach and effectiveness of their activities. Increasingly, they also understand how to manage communications output, not just through traditional channels such as TV and radio, but via digital and social media as well. In many countries industry may be the only institutions set up to communicate at the scale that is required in the current crisis. For these reasons, the government team should enlist business help as early as possible to integrate into the task force. Ministers can begin the process by directly calling on national CEOs for help, ideally asking for some delegation of staff time for communications planning purposes.

Government public health authorities may be unused to dealing with private sector players. The national focal person needs to be able to liaise with and speak the language of business, to respect the speed at which business moves (for example, to engage them only in focused meetings to make quick decisions, rather than in prolonged national committee debates), and to recognise that the private sector is competitive, so companies may not collaborate easily. The government team should also recognise that the desire of business to gain visibility and acknowledgement of their efforts is just as legitimate as that of the usual third sector players.

A good example of how business is working together with government and other players to fight coronavirus is the communication campaign developed by the National Business Compact in Kenya, led by the Marketing Society of Kenya. Multiple soap companies (Unilever, Reckitt-Benkeser, Pwani, Mengengai, Pz Cussons) are contributing not only by giving soap, but by funding a three-month unbranded campaign through mass media and in digital channels. The national brief was approved by the Ministry of Information, Communication and Technology and all materials were approved by the National Emergency Task Force. The brief was executed by BBDO who conceived the national campaign Komesha Corona (Fight Corona) under the authorisation of the government. The soap companies gave media time during prime-time TV, as well as billboard space and radio placements and agreed which of their joint influencers could be used to front the campaign. The marketing directors of the soap companies reviewed the campaign and given feedback. PR and branding of the National Business Compact is being managed on a pro-bono basis by Ogilvy.

\section{Define which behaviours need to change and by whom}

Whilst it may seem obvious at the start, the question of exactly which behaviours need to change is a difficult one. First, evidence as to what works well to prevent community transmission of COVID-19 in the community is scarce. There is controversy, for example, about the utility of wearing of masks, 12 the feasibility of promoting isolation and shielding strategies, and the role of contaminated surfaces and objects in viral transmission. Scientific evidence on COVID-19 transmission is being published at an unprecedented rate, (in December there was no literature but 
by end April 2020 there were 6530 articles published https://www.ncbi.nlm.nih.gov/research/coronavirus/) but there are still many uncertainties.

Two key behaviours around which there is public health consensus are hand hygiene and physical distancing. Handwashing with soap is a particularly plausible intervention in all countries, with a moderate level of evidence that it can be effective in preventing transmission of respiratory viruses. 1314 It can also have other benefits. 15 Unfortunately, we know that the practice is not common in domestic settings in normal times 15 and is difficult to promote, especially when soap and facilities such as water are scarce or inconvenient to use. However, during a pandemic, motivation to practice may increase. 2

Physical distancing is a novel behaviour, which contradicts normal tendencies for people to come into contact, and so has few normal mental cues and interrupts normal routines. It may also be extraordinarily difficult in the context of the informal economies of many low-income countries, where crowded markets workplaces transport hubs and water points form the essential scaffold of economies and livelihoods.

Our current best guess for priority control measures against SARS-COV-2 transmission are summarised in figure 1, which shows how physical distancing and regular handwashing at key moments are key to cutting the transmission routes of the virus.

Figure 1: Breaking the chain of COVID-19 transmission in the community, (distancing and hand hygiene preventive measures shown in red outline, not including surface hygiene and mask wearing).

\section{Infected person}

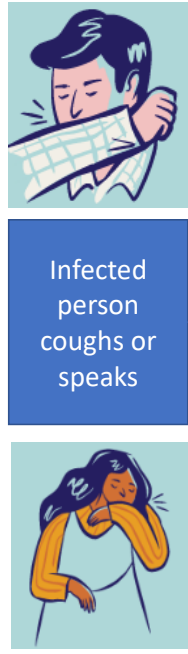

Environment
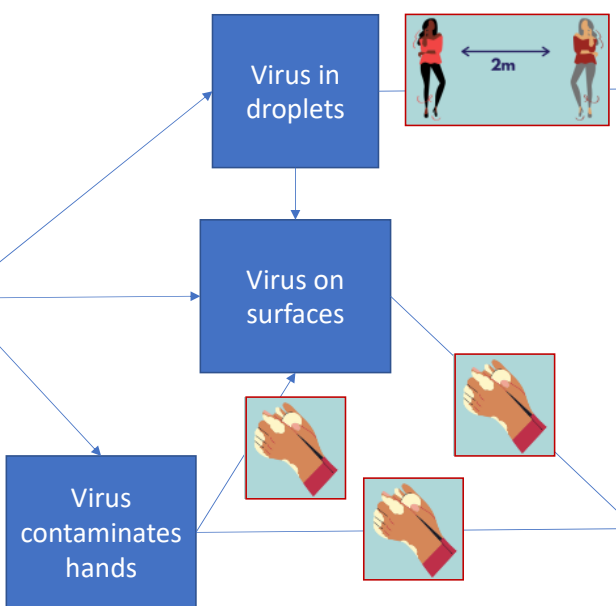

droplets

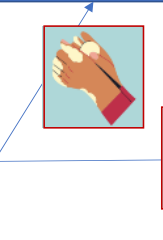

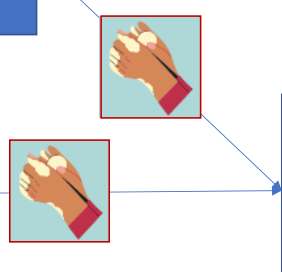

Susceptible

person

breathes in

virus

Susceptible

person touches

virus on surface

or hands
Susceptible person

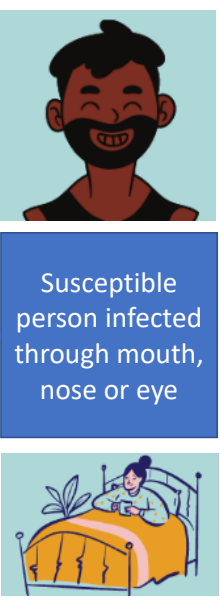


Different behaviours are also expected from different sub-populations. The vulnerable including the poorest, the elderly, the immuno-compromised and the disabled need most protection but often they are in circumstances that make them the hardest to shield from the virus. Key workers need protection in the workplace, but the conditions for physical distancing may not be in place.

International guidelines, from $\mathrm{WHO}$, for example, should form the basis of behavioural targeting, but with careful consideration of what is feasible and sustainable in local circumstances. Advice will change as more evidence comes in, for example, about the benefits and costs of mask wearing in the community.

It is vital that government agree on the key behaviours they wish to promote. These should be simple, coherent, feasible and coherent. For example, in the UK clear mass messages, such as 'wash your hands' and 'stay at home' have been effective, with recent polling showing $94 \%$ of respondents saying they know what they need to do to limit their risk of contracting coronavirus and $98 \%$ of people feeling well informed about physical distancing and how it applies to them.

\section{Review what is already being done internationally and locally}

Whilst every country has different contexts and needs, the simple principles of blocking the transmission of the virus from one human to another remain the same everywhere (figure 1). The epidemiological consequences, however, differ from country to country depending on the demographic, social and physical circumstances and vulnerabilities of the population, as well as by the level and types of control efforts.

Country programmes need to be aware of global developments, without being overwhelmed by the plethora of information appearing on huge numbers of platforms, from many different sources. Most available information is currently focused around the needs of richer countries, which have experienced the virus first, and it is hard to find reliable information relevant for lower income settings. The most authoritative sources should be sought out. These include established, reputable newspapers and news sites on digital media. The most reliable sources are generally academic in nature, but may require prior familiarity with the clinical, modelling, epidemiology and disease control sciences to interpret and it can be hard to see how research findings apply practically. Helpful sources include https://www.thecompassforsbc.org/trending-topics/covid-19-resources-social-andbehavior-change, https://community.ready-initiative.org/ and the COVID -19 Hygiene Hub at LSHTM https://hygienehub.info/covid-19.

A key role for one member of the national task force is to keep under review what is being produced nationally. Good efforts should be highlighted and multiplied, whilst misinformation needs to be spotted and countered speedily. A press subcommittee for the task force can be formed for media advocacy, to encourage responsible journalism. If resources and time allow, a professional PR firm should ideally be brought on board to help to shape the national narrative. 


\section{Review what is known about the drivers of risk behaviours internationally and locally, and rapidly fill in any gaps in knowledge}

As we discuss in the behavioural principles section below, behaviour is not driven by knowledge alone. An effective national communications plan will need to engage the population with information that is new and surprising so as to get and keep its attention, the communications have to be able to motivate action, by making the behaviour something that people will want to do - for a variety of possible reasons and above all, the advocated behaviour has to be possible, as infeasible advice is simply counterproductive. 10

We already know in general what the main drivers of handwashing behaviour during non-pandemic conditions are. First of all people wish to remove any disgusting material from their hands, whether after the toilet, after sneezing or after contacting greasy or dirty material. 4 Second, people wash hands as a sign of good manners, for example to protect others when serving food or shaking hands. 16 This is, to some extent, enforced by social norms, especially when handwashing takes place in public. 17 Nurture of offspring and other relatives is also a well-established motive for handwashing. 18 There is also evidence that handwashing increases in the face of the threat of an epidemic, though it may rapidly return to baseline level afterwards.2 These are global drivers of handwashing and do not seem to vary much between countries. 19

Whilst these motives can all be potent divers of handwashing behaviour, it still takes time and effort to wash hands, and the likelihood of compliance is dependent on the ease of performance. Whilst only small amounts of water and soap are needed, when these are expensive, and/or hard to access, the likelihood of handwashing falls dramatically. 1 National WASH efforts should be ramped up to make domestic water supply more easily available, always with the proviso that this may be hard to achieve for large populations in the short term. There may also be a case for the large-scale production, procurement, placement and management of water tanks and handwash stands, especially for work and educational places (see Box 1). 


\section{Box 1. The WASH response to COVID-19}

Safely managed water, sanitation, and hygiene (WASH) services are an essential part of preventing and protecting human health during infectious disease outbreaks, including the current COVID19 pandemic. Good WASH and waste management practices, that are consistently applied, serve as barriers to human-tohuman transmission of the COVID-19 virus in homes, communities, health care facilities, schools, and other public spaces. Key priority actions include:

- Provision of safe WASH services in health care settings to protect patients, health care workers and staff

- Providing access to WASH facilities in schools, workplaces, markets, prisons, care facilities, transport stations, and other areas where people gather

- Emergency WASH support to the most vulnerable, whether in informal settlements, relief camps or in contexts of displacement due to fragility, conflict and violence.

Adapted from: https://www.worldbank.org/en/topic/water/brief/wash-watersanitation-hygiene-and-covid-19

Much less is currently known about the drivers of distancing behaviours. Disgust of the possibility of being infected by the emanations of others is a natural response to pandemics, but this is not a recommended route to use in promotion, since any invocation of disgust could led to stigmatisation of individuals. 20 Such distancing behaviours also go against a tendency to want to approach and interact with fellow humans, especially in times of distress. Below we discuss what behaviour science can tell us about the drivers of these behaviours internationally.

Aside from motives for safer behaviour, country programmes urgently need to learn more about how to make distancing measures feasible in their own socio-economic contexts. Here local intelligence is critical. Given time and resource, full scale formative research into current behaviour would be desirable, 10 but what can be done speedily and rigorously in a pandemic, potentially under lockdown conditions? First of all, any valid research is better than none. Box 2 provides some suggestions for rapid canvassing of local behaviour and behavioural drivers. The emphasis should be on capturing the voices of those who are less likely to be heard, since decision-makers are generally drawn from urban elites, their anecdotal evidence may not represent what is happening in the general population, especially among those who are socially or physically vulnerable.

\section{Box 2: Methods for rapid data gathering about COVID-10 related behaviour}




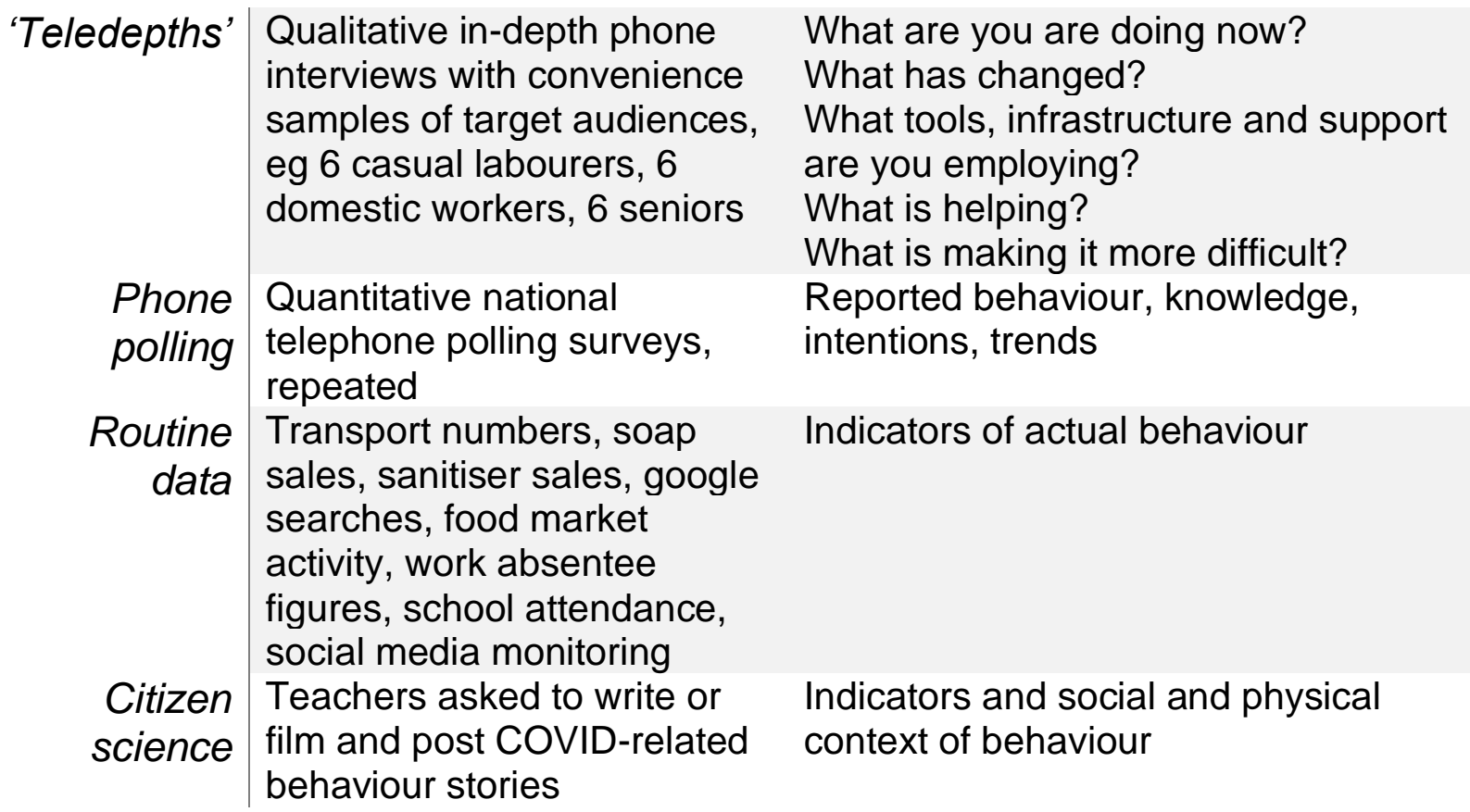

The national task force should commission such rapid research, but also gather reports from other partners with on-the-ground intelligence about existing behaviour and its drivers. A rapid way of extracting salient information is to hold an insight workshop. Here the data are reviewed, then all participants write down on slips of paper any facts that have struck them. These can then be grouped and arranged in order of likely importance. The point of gathering such intelligence is not academic, but to rapidly gain insight as to what is happening, and as to what could cause changes in the desired behaviours. 21 (https://www.Ishtm.ac.uk/sites/default/files/2017-03/BCD\%20Guide.pdf) For example, in an early on-line insight-generation workshop held by a design team in Tanzania it was agreed that the virus could be personified as a coward that liked to skulk and hide, but that could easily be defeated by soap and distancing.

\section{Produce a creative brief and theory of change}

With the team assembled, target behaviours decided and insights about those behaviours marshalled, it is time to begin designing the communications strategy. Box 3 gives an example of a draft creative brief produced to assist in the development of a communications strategy for COVID-19 in Tanzania. Such creative briefs are central to communications campaigns because they summarise the 'musthave' and desirable components for everybody involved. This example includes a problem statement, purpose, objectives, target behaviours, audience data, the persuasive argument, the tone, personality, measures of impact and materials required from the creative team.

Underlying the creative brief is a simple summary theory of change (shown within the document). At a minimum, this sets out how the communications intervention will change the social and physical environment in which people live (including the messaging they see), how this will change something in their minds persuasively (through motivation, beliefs, habits), how this will change their behaviour, and how 
this will reduce the risk of transmission. 10 The theory of change provides the links in the chain from intervention to impact and serves to constantly remind the team that if any of the links are broken, the communications chain will be ineffective. It also serves as a guide as to what factors need to be monitored and evaluated throughout the intervention chain and for identifying any unintended harms caused by the intervention. 22

In normal times, such a creative brief would be sent out to professional creative teams to bid to create a national communications campaign. The best technical and financial proposal would be selected, the company would be contracted and a design process with numerous steps of creation and reverts would be instigated. In an emergency such as this, however, the process has to be short-circuited. The task force will need to find rapid means to source creative inputs. Help can be sought from the private sector, as set out above, and from international organisations with skills in communications. Whilst all will be used to working from creative briefs, it is important to note that every client and every creative organisation employs different language about the creation of content and the task force will need to devote time to 'getting on the same page'.

\section{Develop a unifying national brand}

With a creative team on board, the first task is to develop a unifying national brand. Whilst the bombardment of materials coming from many directions has raised awareness about the problem of the coronavirus pandemic in most countries, authoritative instructions and advice about what to do about it often still remains confused. Governments needs to rapidly brand their national campaigns to help to establish authority and ensure coherence.

A brand usually involves (at minimum) a slogan and a logo. The logo should be recognisably based on existing government brands but needs to have new, eyecatching elements. The slogan should very briefly encapsulate the primary insight of the campaign, as set out in the brief. For example, the New Zealand government's COVID-19 brand (https://covid19.govt.nz) has a slogan, 'Unite against covid-19', uses consistent pictorial symbols, has a black and yellow diagonal stripe that alludes to the hazard tape used at an accident scene, employs a simple, friendly typeface and presents information that is clear, precise, pragmatic and accessible.

\section{Develop executions employing the most relevant channels for the target audiences}

With a brand established, the next task is to develop creative materials such as ads, posters and other media that embody the brand message and insight. These have to be designed to fit the dominant channels of communication in society, which should have been set out in the brief. Content may take the form of standard TV and radio commercials, or of 'memes' for social media, or of content for existing TV and radio shows to generate discussion and social media sharing.

In lockdown conditions, live shooting or recording may create difficulties. However, these can be overcome through $\mathrm{CGl}$, animation and remote conferencing. For messaging to go viral it must be worth sharing, i.e. one person who sees the 'meme' must believe it will entertain or enlighten the next person to see it. It must serve as a desirable gift, not just noise. This makes it all the more important that content is 
surprising, engaging, enlightening and useful to people. For executions to be effective they should show the target behaviours in their actual settings, and acknowledge the limitations of how far it will be possible to actually carry them out. Box 4 sets out some examples of good communications materials along with some explanation of why they are likely to be effective.

\section{Box 4. Examples of potentially powerful communications materials on COVID-} 19

\begin{tabular}{|c|c|c|c|}
\hline Name & Concept & Theory of change & Source \\
\hline $\begin{array}{r}\text { Corona Virus } \\
\text { Alert }\end{array}$ & $\begin{array}{l}\text { People need to } \\
\text { learn about new } \\
\text { virus and how to } \\
\text { respond }\end{array}$ & $\begin{array}{l}\text { Educational, but with a } \\
\text { catchy song making the } \\
\text { message memorable; } \\
\text { seeing everyone play/sing } \\
\text { the song can promote new } \\
\text { norms of behaviour }\end{array}$ & $\begin{array}{l}\text { Bobi Wine and } \\
\text { Nubian Li } \\
\text { (Ugandan } \\
\text { singers) }\end{array}$ \\
\hline $\begin{array}{r}\text { Ping Pong } \\
\text { Balls }\end{array}$ & $\begin{array}{l}\text { Visual } \\
\text { demonstration of } \\
\text { effect of physical } \\
\text { distancing on } \\
\text { transmission }\end{array}$ & $\begin{array}{l}\text { Seeing consequences } \\
\text { instantaneously at a } \\
\text { 'population' level is more } \\
\text { comprehensible to our } \\
\text { visually-oriented brains }\end{array}$ & $\begin{array}{l}\text { Ohio State } \\
\text { Department of } \\
\text { Health }\end{array}$ \\
\hline $\begin{array}{r}\text { Komboni } \\
\text { Housewives }\end{array}$ & $\begin{array}{r}\text { People who wash } \\
\text { hands are 'one of } \\
\text { us' }\end{array}$ & $\begin{array}{r}\text { Neighbours may gossip } \\
\text { about you if you don't wash } \\
\text { your hands, but they would } \\
\text { be wrong! }\end{array}$ & $\begin{array}{r}\text { Zambia } \\
\text { Ministry of } \\
\text { Health/CIDRZ/ } \\
\text { LSHTM }\end{array}$ \\
\hline ‘Unstoppables' & $\begin{array}{l}\text { We should praise } \\
\text { some people for } \\
\text { violating the new } \\
\text { norms }\end{array}$ & $\begin{array}{c}\text { Truck drivers move } \\
\text { constantly from place to } \\
\text { place, getting close to each } \\
\text { other, but are delivering vital } \\
\text { resources to those that need } \\
\text { them }\end{array}$ & $\begin{array}{l}\text { Iveco } \\
\text { (Ogilvy } \\
\text { agency) }\end{array}$ \\
\hline $\begin{array}{l}\text { 'Play for the } \\
\text { world' }\end{array}$ & $\begin{array}{l}\text { People who } \\
\text { exercise at home } \\
\text { are heroic for } \\
\text { ensuring they don't } \\
\text { expose others }\end{array}$ & $\begin{array}{l}\text { Celebrating personal } \\
\text { hardship as socially } \\
\text { valuable makes people } \\
\text { more likely to avoid going } \\
\text { back into social contexts }\end{array}$ & Nike \\
\hline $\begin{array}{r}\text { 'Spoiler' } \\
\text { Campaign }\end{array}$ & $\begin{array}{l}\text { Get people to avoid } \\
\text { public places by } \\
\text { putting up } \\
\text { billboards that } \\
\text { 'spoil' plot-points on } \\
\text { popular shows }\end{array}$ & $\begin{array}{c}\text { People won't want to be } \\
\text { exposed to these 'spoilers' } \\
\text { and so will stay home where } \\
\text { they belong }\end{array}$ & $\begin{array}{l}\text { Miami Ad } \\
\text { School } \\
\text { [student- } \\
\text { designed } \\
\text { campaign] }\end{array}$ \\
\hline $\begin{array}{r}\text { Universidade } \\
\text { do Futebol }\end{array}$ & $\begin{array}{l}\text { Uncomfortable } \\
\text { reminder of } \\
\text { moments when }\end{array}$ & $\begin{array}{r}\text { Whilst refusing to shake } \\
\text { hands may seem rude, } \\
\text { nowadays people are }\end{array}$ & $\begin{array}{r}\text { Liberdade } \\
\text { agency }\end{array}$ \\
\hline
\end{tabular}


footballers refused actually showing their social

to shake hands conscience

\begin{abstract}
9. Rapidly pre-test and continually revise materials
In an ideal world, new content is pretested with samples of target audiences to establish comprehensibility, believability, engagement, likeability and the likelihood that it will be acted upon. In emergency conditions, some pretesting, for example through phone calls with small samples of target audiences, will still be valuable, allowing course corrections before poorly-performing materials are released.
\end{abstract}

Content will also need to be revised and refreshed often, as the impact of communications diminishes as surprise fades and circumstances evolve (including government policies about what is required at a given stage to control the disease). It may be possible, however, to develop an evolving story line, with engaging characters whose behaviour gradually evolves as the situation develops. An example is the Soul City TV and radio series broadcast from South Africa, anchored in the reality of life in a poor community, that has covered a large range of evolving health and social issues including mother and child health, HIV, cancer and alcohol abuse.

\title{
10. Monitor, evaluate, and share lessons
}

Continual monitoring of the effect of communications on behaviour and behavioural indicators is essential to allow course corrections. For example, in the UK when it became obvious that public transport use had fallen to some $10 \%$ of pre-pandemic levels, it was realised that it would not be necessary to focus on reducing the use of public transport in communications. Usage will be continue to be closely monitored as and when lockdown measures are relaxed.

Monitoring of the effect of communications, however, offers particular challenges in pandemic circumstances. Industry, however, is well used to using professional telephone panel survey companies to remotely monitor the effects of their brandrelated communications. Such companies are now offering their services in the current pandemic. For example, Geopoll has conducted a remote SMS study of the effects that coronavirus is having in 12 African countries. $96 \%$ of participants reported that they had taken measures to protect themselves by increasing handwashing and avoiding public places, for example. $90 \%$ of Rwandans (who are under lockdown) reported staying home whilst only $57 \%$ of Beninois said that they were. In the sample, trust that government was doing the right thing was highest in Rwanda and lowest in Kenya. 23

Because these surveys will be repeated at regular intervals they can provide indicators of the success, or otherwise, of government-led communication programmes. It is, of course, recognised that such surveys inevitably oversample the literate and the phone user. To counter this, special surveys could be commissioned targeting the old and the vulnerable, by reaching members of their families, for example. They can also be used to detect the unintended consequences of an intervention, as for example, when, in the above survey, $80 \%$ of respondents said 
that they were worried that they would not have enough food to eat, mainly due to local market closures.

There are multiple existing and new international fora exchanging information and learning about COVID-19. Whilst joining such fora may not seem a priority at the start of an emergency, COVID-19 is a global problem and reciprocal efforts to share lessons will pay off eventually for the whole planet.

\section{Behavioural principles}

We now move to a more detailed explanation of how behavioural principles can work to encourage behaviour change. The first three principles were developed in the context of the UK COVID-19 response 24 and last three apply to communications in general.

\section{Do it for others:}

People will often readily engage in behaviours to protect themselves in the face of an obvious risk. Fear of getting ill from a virus will increase rates of handwashing after coming home from a trip outside, for example. However, many of the recommended behaviours are about reducing the likelihood of those who may not yet be symptomatic from spreading it to others. Luckily, people are not just motivated to help themselves, as altruistic behaviour is a feature of all human societies 25. For example, moral elevation is inspired by others' prosocial, selfless acts, and this experience prompts observers to also act with kindness and generosity themselves 26.

Natural human prosocial motives can be engaged in a number of ways. A preliminary study provides some evidence that public health messaging focused on duties and responsibilities toward family, friends and fellow citizens may be more effective than focusing on self-preservation in the case of COVID-related behaviour. 27 According to van Bevel et al, 28 highlighting exemplary selfless behaviour and sacrifice could produce a contagion of a different kind, namely one of prosocial behaviour and cooperation. Another trick that can be used is to make specific reference to close relatives in the first instance (invoking the natural urge to nurture our genetic kin), but also use terminology for 'extended kinship' for larger groups to which we naturally affiliate, such as 'we are all brothers' in a social group or community 29.

Affiliation is another motive that can be used in this context - people wish to maintain their status as members in good standing of desirable groups, and to conform to the norms of those groups. Emphasizing new normative standards for good membership - such as engaging in physical distancing from others whenever away from home can be powerful motivations. Communications need to make these norms highly visible, and stress how everybody is 'doing the right thing' (without focusing on cheaters, which can backfire), for example 3016.

Somewhat more controversially, it is also possible to use social punishments to reprimand or restrict those putting others at risk through behaviours like attending social gatherings. When legitimate authorities set out legal punishments they are making expected behaviour very clear to people. Physical distancing and 
handwashing can be couched as good manners, with those who do not follow risking social opprobrium, for example 31. Most often such punishments do not even need to be enforced to be effective 32. Heavy-handed or unfair enforcement can be counterproductive, leading to rejection, or revolt and a lessening of the authority of institutions 33.

\section{Act together:}

It is commonly assumed that crises produce public disorder such as hoarding, looting and violence. In fact, in such circumstances people are more likely to engage in social solidarity for public benefit. According to Reicher et al, writing about COVID19:

"To the contrary, research on behaviour in emergencies and disasters shows that people are characteristically resilient: they act in an orderly way, they support each other, they (rather than the emergency services) constitute the real 'first responders' in a crisis. Moreover, this is particularly likely to occur if people form a sense of shared identity (of 'we-ness') and come together collectively. Indeed, more generally there is a growing body of evidence to show that when people work with each other as members of a group rather than work against each other as individuals, they are more likely to provide mutual support and are better able to cope with challenging circumstances." 34

Epidemiologically speaking, the vast majority of people need to conform with spreadreducing strictures for there to be a significant effect on morbidity and mortality. A few defectors can put the sacrifice of the whole group at risk. Highlighting this fact adds moral pressure to conform to the new rules of behaviour. It is vital again to get the right balance between referring to good and bad behaviour. One rule is to make sure not to show or mention current non-compliance (such as the fact that many don't handwash with soap) in the communication itself, which can give people permission not to do what is being requested 35 . It is important to ensure that the press understand the importance of this point, since pointing the finger at bad behaviour is a common trope in news feeds.

\section{Facilitate trust}

Communications are only effective when they are trusted. 36 This is one reason why products use brands - as a guarantee that they can be held to account for what they produce. 37. The same is true of national institutions, which have vital roles to play in coordinating social responses to disasters. This trust is precious and government brands need nurturing through crises. First of all, government has to be transparent, by admitting what they know and what they do not know (and a lot still remains unknown about this virus). They should make clear the distinction between science and politics, publish their data, explain their sources, and their reasoning for adopting particular strategies.

Second, communications should employ trusted sources: Marketers have long found it profitable to use members of trusted groups, such as doctors or celebrities, as vehicles for their messaging. The trusted spokespeople should be recognised by their communities and be relevant to the content of the message. In present circumstances, that can mean most obviously public health authorities, who need to be able to speak with confidence and experience. Trying to cover up for failings, 
rather than acknowledging them tends to be counterproductive of trust since it is hard to disguise from the public. Religious leaders can be trusted figures, but may also spread misinformation and bad advice (as in the case of those who advocate coming together for religious services in the face of government recommendations).

\section{Make it possible:}

Providing advice that is clearly not feasible or requires inordinate sacrifice is likely to be counterproductive. People are more likely to engage in behaviours that require minimum time, physical effort or cognitive load. Any means that can be found to reduce the costs of performing the target behaviours will mean people become more likely to do them. Messaging can help people to figure out how to reduce costs for themselves. For example, ensuring they have put soap and a bowl of water in the place where they are likely to handwash can reduce the time required. Alternatively, some measures reduce the perception of one of these costs. For example, turning something into a game that is competitive with others can make the time spent in an onerous task go by faster, as when online communal activities induce pleasure or reduce a sense of social isolation. Box 1 has discussed the importance of providing WASH infrastructure to make it feasible to follow hygiene advice.

\section{Get attention:}

It is always necessary to create communications that attract attention in order to ensure mental processing of what is being said or demonstrated. However, in the current situation of a pandemic, this is even more critical as the volume of what is being currently communicated through a large number of different channels can be overwhelming. For this reason, communications about COVID-19 must be surprising - in the sense of being unexpected in some way.38 The channel itself can sometimes be surprising - seeing a respected government figure on Instagram, for example, might be a 'first' for many in some countries. Having the Prime Minister of Ethiopia demonstrate how to do handwashing, as part of a '\#SafeHandsChallenge' might be even more unexpected.

Standard messages must be presented in a new way with a new angle and new insight. For example, the Nike ad referred to above in Box 3 is surprising in that it suggests that we can all be champions, even from our bedrooms.

\section{Emphasize reward:}

People do things because they are rewarding. These rewards can be physical, like money or food, or social like praise or acceptance into a group. In any case, they are always translated into psychological rewards via the dopaminergic system of the brain 3940 . Making sure people understand and appreciate all the possible physical and social rewards from doing the target behaviours can be important when the behaviours are new (as in the case of physical distancing), and when they seem to be unrewarding (as in the case of self-isolation). This is why many COVID-19 communications emphasize how staying at home benefits others about whom one cares deeply. Constant congratulation of the public for following recommended measures is a reward strategy used in press briefings by the French government, for example. 


\section{Conclusions}

Whilst emergencies are not generally conducive to strategic thinking, in the current COVID-19 pandemic it is vital that country governments take responsibility for the organisation and coordination of national behaviour change strategies (in tandem with taking the actions that make behaviour change possible). In this short guide we have set out some steps and principles that can help to guide the rapid development of national communications campaigns. Whilst we recognize that every government will want to 'own' its own communication strategy, and fit its content to their particular circumstances, it is still the case that there are general principles of communication that should be followed to ensure maximal impact, because only by following a creative process can truly effective approaches to behaviour change be identified.

This document was written in response to the fact that too few countries currently have strong technical expertise and robust institutional structures to be able to conduct professional public health communication programmes, even in the best of times. Whilst the context of an emergency is far from the best of times, the major focus that is currently being placed on behaviour change should remind countries that they will always need this capacity. Every country should have a policy to continually improve their ability to do strategic communications in a sustainable fashion, pandemic or no.

\section{References}

1. White $S$, Thorseth $A H$, Dreibelbis $R$, et al. The determinants of handwashing behaviour in domestic settings: An integrative systematic review. International Journal of Hygiene and Environmental Health 2020;227:113512.

2. Fleischman DS, Webster GD, Judah G, et al. Sensor recorded changes in rates of hand washing with soap in response to the media reports of the H1N1 pandemic in Britain. BMJ Open 2011;1(2)

3. Czerniewska A, White S. Hygiene programming during outbreaks: a qualitative case study of the humanitarian response during the Ebola outbreak in Liberia. BMC Public Health 2020;20(1):154.

4. Curtis V, Danquah L, Aunger R. Planned, motivated and habitual hygiene behaviour: an eleven country review. Health Education Research 2009;24(4):655-73.

5. Czerniewska A, Muangi WC, Aunger R, et al. Theory-driven formative research to inform the design of a national sanitation campaign in Tanzania. PloS one 2019;14(8)

6. Curtis V. Explaining the outcomes of the'Clean India'campaign: institutional behaviour and sanitation transformation in India. BMJ global health 2019;4(5):e001892.

7. Iyer P, Sara J, Curtis V, et al. The handwashing handbook. A guide for developing a hygiene promotion program to increase handwashing with soap. Washington, $D C$ : Water and Sanitation Program 2005

8. Sidibe M. Marketing meets mission. Harvard Business Review 2020(May-June 2020):134.

9. Curtis V, Garbrah-Aidoo N, Scott B. Masters of Marketing: Bringing Private Sector Skills to Public Health Partnerships. American Journal of Public Health 2007; 97 (4):634-41.

10. Aunger R, Curtis V. Behaviour Centred Design: towards an applied science of behaviour change. Health psychology review 2016;10(4):425-46. 
11. Donovan R, Henley N. Social marketing: Principles and practice. East Hawthorn: IP Communications 2003.

12. Mahase E. Covid-19: What is the evidence for cloth masks? BMJ 2020;369:m1422. doi: 10.1136/bmj.m1422

13. Rabie T, Curtis V. Handwashing and risk of respiratory infections: a quantitative systematic review. Tropical Medicine \& International Health 2006;11(3):269-78.

14. Fung IC, Cairncross S. Effectiveness of handwashing in preventing SARS: a review. Tropical medicine \& international health : TM \& IH 2006;11(11):1749-58. doi: 10.1111/j.1365-3156.2006.01734.x [published Online First: 2006/10/24]

15. Freeman MC, Stocks ME, Cumming $O$, et al. Systematic review: Hygiene and health: systematic review of handwashing practices worldwide and update of health effects. Tropical Medicine \& International Health 2014;19(8):906-16.

16. Curtis V. Don't look, don't touch, the science behind revulsion. Oxford: Oxford University Press 2013.

17. G Judah, R Aunger, WP Schmidt, et al. Experimental Pretesting of Hand-Washing Interventions in a Natural Setting American Journal of Public Health 2009;99(S2):S405-11.

18. Aunger R, Schmidt WP, Ranpura A, et al. Three kinds of psychological determinants for hand-washing behaviour in Kenya. Soc Sci Med 2010;70(3):383-91. doi: 10.1016/j.socscimed.2009.10.038 [published Online First: 2009/11/17]

19. Aunger R, Greenland K, Ploubidis $G$, et al. The determinants of reported personal and household hygiene behaviour: A multi-country study. PloS one 2016;11(8):e0159551.

20. Curtis V. Don't Look, Don't Touch, Don't Eat: The Science Behind Revulsion. Chicago: University of Chicago Press 2013.

21. Brown T. Change by Design: How Design Thinking transforms organizations and inspires innovation. New York: HarperCollins 2009.

22. Bonell C, Jamal F, Melendez-Torres GJ, et al. 'Dark logic': theorising the harmful consequences of public health interventions. J Epidemiol Community Health 2015;69(1):95-8. doi: 10.1136/jech-2014-204671 [published Online First: 2014/11/19]

23. Geopoll. Coronavirus in Sub-Saharan Africa: | How Africans in 12 nations are reponding to the covid-19 outbreak

, 2020.

24. Bonell C, Michie S, Reicher S, et al. Harnessing behavioural science in public health campaigns to maintain 'physical distancing' in response to the COVID-19 pandemic: key principles. Journal of Epidemiology and Community Health (under review)

25. Gintis H, Bowles S, Boyd RT, et al. Moral sentiments and material interests: The foundations of cooperation in economic life: MIT press 2005.

26. Schnall S, Roper J, Fessler DM. Elevation leads to altruistic behavior. Psychological science 2010;21(3):315-20.

27. Everett JA, Colombatto C, Chituc V, et al. The effectiveness of moral messages on public health behavioral intentions during the COVID-19 pandemic. 2020

28. Van Bavel JJ, Boggio P, Capraro V, et al. Using social and behavioural science to support COVID-19 pandemic response. 2020

29. Qirko H. Kinship appeals and conservation social marketing. Biodiversity and conservation 2017;26(5):1009-26. 
30. Bicchieri C. Norms in the wild: How to diagnose, measure, and change social norms: Oxford University Press 2016.

31. Curtis V. Manners maketh man: How disgust shaped human evolution. New Scientist 2013;219(2935):28-29.

32. Sigmund K. Punish or perish? Retaliation and collaboration among humans. Trends in ecology \& evolution 2007;22(11):593-600.

33. Ostrom E. Governing the commons: The evolution of institutions for collective action: Cambridge university press 1990.

34. Stephen Reicher, Clifford Stott, John Drury, et al. Facilitating Adherence to Physical distancing Measures during the COVID 19 Pandemic. BMJ Analysis (Submitted)

35. Goldstein NJ, Cialdini RB, Griskevicius V. A room with a viewpoint: Using social norms to motivate environmental conservation in hotels. Journal of Consumer Research 2008;35(3):472-82.

36. Mercier H, Sperber D. The enigma of reason: Harvard University Press 2017.

37. Keller KL, Brexendorf TO. Measuring brand equity. Handbuch Markenführung: Springer 2019:1409-39.

38. Friston K. The free-energy principle: a unified brain theory? Nature reviews neuroscience 2010;11(2):127-38.

39. Schultz W. Predictive reward signal of dopamine neurons. Journal of neurophysiology 1998;80(1):1-27.

40. Schultz W. Behavioral theories and the neurophysiology of reward. Annu Rev Psychol 2006;57:87-115.

Box 2: Example of a creative brief

\begin{tabular}{|c|c|c|}
\hline ACTIVITY NAME & \multicolumn{2}{|c|}{ COVID-19 Communication Brief } \\
\hline CLIENT NAME & \multicolumn{2}{|c|}{ Tanzania Ministry of Health } \\
\hline DATE & \multicolumn{2}{|c|}{ April 30, 2020} \\
\hline \multirow{3}{*}{ CLIENT CONTACT } & NAME & National focal person \\
\hline & PHONE & $555-5555$ \\
\hline & EMAIL & NFP@MoH.gov \\
\hline \multicolumn{3}{|c|}{ PURPOSE | The problem } \\
\hline \multicolumn{3}{|c|}{$\begin{array}{l}\text { The purpose of this brief is to coordinate the design, planning and execution of } \\
\text { compassionate, engaging and empowering communication materials in order to develop and } \\
\text { sustain the health behaviours that will stop the spread of COVID-19 disease. The focus is on } \\
\text { Personal and Social Protective Behaviours such as practising personal hygiene, maintaining } \\
\text { physical distance, wearing masks in public and self-isolation in case of symptoms. }\end{array}$} \\
\hline \multicolumn{3}{|c|}{ Minimizing morbidity and mortality from COVID-19 in Tanzania } \\
\hline \multicolumn{3}{|c|}{ COMMUNICATION OBJECTIVES } \\
\hline \multicolumn{3}{|c|}{ What does the communication want to achieve } \\
\hline
\end{tabular}


Make everyone want to help stop the spread of COVID-19 by practising the Personal and Social Protective Behaviours desired by the government.

CAMPAIGN AUDIENCE

COMMUNICATION TARGET | who are we trying to reach?

Primary

- Young people, 15-35. They are both the most exposed to the economic impact but also have a perception of invulnerability. They are slowest to adopt the behaviours necessary to flatten the curve. And while not as vulnerable as higher risk groups, they are not immune either.

Secondary

- Seniors and those with chronic health condition most vulnerable to COVID-19

- Potential partners who are willing to support the cause

- Political leaders and government

Profile of our primary audience:

- Speak and understand the national language and their own vernacular languages

- Travellers, self-employed and petty traders working hard to secure their future and most susceptible to catching and transmitting COVID-19 (but need practical information about how to safely continue earning a living).

- Families care about protecting their loved ones (but how to do so practically is not clear)

- Urban audience currently most at risk have GOOD access to TV, radio and social media via smart phones.

- Rural audience have LOW proliferation of smart phones, little access to social media pages. $50 \%$ listen to radio regularly. TV and cinema are currently watched in public places and information spreads by word of mouth, eg marketplaces.

\section{PROJECT TARGET | What change are we looking for?}

GET heads of households and families

TO practice Personal and Social Protective Behaviours in the community

i.e., Handwashing with soap more frequently, physical distancing, wearing masks in public and isolation of the symptomatic

BY convincing them that they can help save lives

\section{PERSUASIVE ARGUMENT}

\begin{tabular}{|c|c|c|c|c|}
\hline \multicolumn{5}{|c|}{ UASIVE AR } \\
\hline \multicolumn{5}{|c|}{ Theory of Change } \\
\hline $\begin{array}{l}\text { Designed } \\
\text { message } \\
\text { content; } \\
\text { Supportive } \\
\text { supplies }\end{array}$ & $\begin{array}{l}\text { Target audience } \\
\text { exposed to } \\
\text { messages and } \\
\text { physical/social } \\
\text { supports }\end{array}$ & $\begin{array}{l}\text { I want to protect } \\
\text { myself and } \\
\text { others from } \\
\text { Coronavirus }\end{array}$ & $\begin{array}{l}\text { Practice of } \\
\text { Personal and } \\
\text { Social Protection } \\
\text { Behaviours }\end{array}$ & $\begin{array}{c}\text { Reduced } \\
\text { transmission and } \\
\text { impact of } \\
\text { COVID-19 in } \\
\text { country }\end{array}$ \\
\hline Intervention & Environment & Brain & Behaviour & \\
\hline [Inputs] & [Implementation] & [Outputs] & [Outcomes] & [Impact] \\
\hline \multicolumn{5}{|c|}{ THE TAKEAWAY | What is the key message? } \\
\hline \multicolumn{5}{|c|}{$\begin{array}{l}\text { We must all protect ourselves and others from the spread of coronavirus } \\
\text { To reduce this spread we need to act together } \\
\text { Everyone depends on each other to achieve this } \\
\text { Therefore, we all have obligations to each other: } \\
\text { 'Don't take it lightly, You are depended upon!' }\end{array}$} \\
\hline & PAIGN TONE & hat traits & ying to & \\
\hline
\end{tabular}


Relevance, Compassion, Empowerment, Solidarity

\section{CAMPAIGN PERSONALITY | What characteristics define the campaign?}

Professional, Rational, Informed, Confident, Reassuring

\section{DESIGN PRINCIPLES}

- Scalable to national level at reasonable cost and with reasonable logistics

- No direct focus on health; no death/disease/pathogens: not clinical or 'public healthy' in tone/feel

- Focus on changing behaviour, not awareness

- Emphasize the emotional as well as logical

- Communicate through common understandings, story arc, and show more than tell

- Materials must show benefit/consequence to target audience

\section{MEASURES OF IMPACT}

1. Scale of reach and engagement

2. Integration of above-the-line with the below-the-line communications

3. Presence of key influencers behind the campaign

All materials:

\section{WHAT IS REQUIRED?}

- Must be engaging and memorable

- Must reflect the overall brand

- Should reflect the cultural nuances of different regions

- Should unite people

Acknowledgements: Thanks to Naima Sakande for the illustration, Paul Deverill for comments and members of the UK SPI-B committee on COVID-19 for their wisdom. 